Article

\title{
Deubiquitinylase USP47 Promotes RelA Phosphorylation and Survival in Gastric Cancer Cells
}

\author{
Lara Naghavi ${ }^{\dagger}$, Martin Schwalbe $^{\dagger}$, Ahmed Ghanem and Michael Naumann * (10) \\ Institute of Experimental Internal Medicine, Otto von Guericke University, 39120 Magdeburg, Germany; \\ lara.naghavi@med.ovgu.de (L.N.); martin.schwalbe@med.ovgu.de (M.S.); ahmed.ghanem@med.ovgu.de (A.G.) \\ * Correspondence: Naumann@med.ovgu.de; Tel.: +49-391-671-3227 \\ + These authors contributed equally to this work.
}

Received: 13 February 2018; Accepted: 12 May 2018; Published: 22 May 2018

\begin{abstract}
Every year, gastric cancer causes around 819,000 deaths worldwide. The incidence of gastric cancer in the western world is slowly declining, but the prognosis is unpromising. In Germany, the 5-year-survival rate is around $32 \%$, and the average life span after diagnosis is 6 to 9 months. Therapy of gastric cancer patients comprises a gastrectomy and perioperative or adjuvant chemotherapy. However, resistance of gastric cancer cells to these agents is widespread; thus, improved chemotherapeutic approaches are required. Nuclear factor kappa B (NF- $\mathrm{BB})$ transcription factors are associated with anti-apoptosis, carcinogenesis, and chemoresistance, and thus, constitute attractive targets for therapeutic intervention. In immunoblots, we show that ubiquitin specific protease 47 (USP47) promotes $\beta$-transducin repeat-containing protein $(\beta \operatorname{TrCP})$ stability and phosphorylation of RelA. Furthermore, after knockdown of USP47 by RNA interference, we analyzed in gastric cancer cell lines metabolic activity/viability in an MTT assay, and apoptotic cell death by Annexin V staining and poly(ADP-Ribose) polymerase (PARP)-1, caspase 3, and caspase 8 cleavage, respectively. We found that USP47 contributes to cell viability and chemoresistance in NCI-N87 gastric carcinoma cells treated with etoposide and camptothecin. Inhibition of USP47 might be a suitable strategy to downregulate NF-KB activity, and to overcome chemoresistance in gastric cancer.
\end{abstract}

Keywords: deubiquitinylases; NF-kB signaling; apoptotic cell death; gastric carcinoma; therapeutic targets; chemoresistance; ubiquitin-specific proteases

\section{Introduction}

With 1.3 million incident cases and 819,000 deaths recorded globally, gastric cancer was the fifth most common malignancy, and the third leading cause of cancer deaths in 2015 [1]. Surgical gastrectomy remains the only curative therapy. However, relapse occurs in $40-60 \%$ of cases [2]. Diagnosis of gastric cancers often occurs when tumors are inoperable and patients have median survival times of three to five months. First-line or adjuvant chemotherapy (or chemoradiation) extends patient survival times by 6-7 months [3]. The high number of deaths from gastric cancer, low cure rates, and tumor relapse after gastrectomy therefore demand the development of better chemotherapeutic agents to improve patient survival. In particular, overcoming chemoresistance in tumor cells that otherwise could result in relapse or metastasis poses a major challenge $[4,5]$.

Nuclear factor kappa B (NF-kB) constitutes a family of transcription factors (RelA, RelB, c-Rel, p105/p50 and p100/52) that regulate many target genes involved in inflammation, immunity, cell proliferation, or cell survival. Without stimulation, NF- $\mathrm{BB}$ molecules are sequestered to the cytoplasm by inhibitors of kappa B (IKB) molecules. Stimulation of the canonical NF- $\mathrm{KB}$ pathway results in the activation of the IKB kinase (IKK) complex, which in turn phosphorylates IKB $\alpha$, 
promoting its ubiquitinylation and subsequent degradation. After release from I $\mathrm{K} B \alpha, \mathrm{NF}-\mathrm{k} B$ factors translocate to the nucleus stimulating transcription of their target genes. Transcriptional activity of NF- $\mathrm{kB}$ is further regulated by posttranslational modifications like phosphorylation, ubiquitinylation, or acetylation [6]. Importantly, dysregulation of NF- $\mathrm{KB}$ signaling promotes carcinogenesis $[5,7,8]$ and chemoresistance [9-11].

As novel therapeutic targets, deubiquitinylases are receiving increased attention, due to their association with cancer and neurodegenerative diseases [12,13]. Deubiquitinylases (DUBs) as antagonists to E3 ubiquitin ligases are an integral part of the ubiquitin-proteasome-system. E3s conjugate ubiquitin moieties to substrate proteins, and thus, regulate their stability, protein interactions, or subcellular localization. In contrast, to the more than 600 E3 ligases [14] in humans with distinct substrate specificities, less than 100 DUBs reverse the conjugation and cleave ubiquitin moieties from substrate proteins. In particular, within the NF- $\mathrm{kB}$ pathway, E3s and DUBs regulate IKK complex activation, I $\mathrm{K} \mathrm{B} \alpha$ degradation, or NF- $\mathrm{kB}$ activity [15-17]. Because the NF- $\kappa B$ pathway constitutes an attractive target for therapeutic intervention in gastric cancer $[5,18]$, we performed an siRNA screen aiming to identify potential DUB targets that are essential for NF- $\mathrm{kB}$ activity. As one such target, we identified the ubiquitin specific protease 47 (USP47), that was previously shown to be essential for the proliferation of gastric carcinomas [19]. Furthermore, depletion of USP47 sensitized osteosarcoma and breast cancer cell lines towards drug and UV radiation-induced apoptosis [20].

In this study, we addressed the molecular details of NF- $\mathrm{KB}$ regulation using USP47, and examined the viability of USP47 as a promising target for drug intervention to enhance the action of current drugs, and to overcome chemoresistance in gastric cancer cells. Our results show that depletion of USP47 in AGS gastric cancer cells results in decreased protein levels of phospho-RelA and $\beta$-transducin repeat-containing protein $(\beta \operatorname{TrCP})$. Even though USP47 depletion failed to increase apoptotic cell death in AGS cells treated with camptothecin (CPT) and etoposide (Eto), it overcame chemoresistance in NCI-N87 gastric carcinoma cells. Therefore, targeting of USP47 represents a suitable strategy to overcome drug resistance in gastric carcinomas.

\section{Experimental Section}

\subsection{Cell Culture and siRNA Transfection}

Gastric carcinoma cell lines AGS and NCI-N87 (ATCC, LGC Standards GmbH, Wesel, Germany) were cultured in an RPMI 1640 medium, supplemented with $10 \%$ fetal calf serum (FCS) and $100 \mathrm{U} / \mathrm{mL}$ penicillin/streptomycin, and then incubated at $37{ }^{\circ} \mathrm{C}$ in a $5 \% \mathrm{CO}_{2}$ humidified incubator. AGS and NCI-N87 cells were seeded at a density of 1.2 or $1.5 \times 10^{6}$, respectively, per $100 \mathrm{~mm}$ culture dish (CellStar, Greiner Bio-one GmbH, Frickenhausen, Germany). For transient knockdown of USP47, cells at 30\% confluency were transferred into serum-free OptiMEM medium (Thermo Fisher Scientific, Waltham, MA, USA), and transfected with $50 \mathrm{nM}$ siRNA that had been mixed with $10 \mu \mathrm{L} / 10 \mathrm{~cm}$ culture dish SiLentFect Lipid Reagent (Bio-Rad, Hercules, CA, USA). USP47 siRNA 5'-CUAUAACUGUUCGUGCUUA-3' was obtained from Eurofins Genomics, Ebersberg, Germany, and AllStars negative control siRNA from Qiagen, Hilden, Germany. Six hours after transfection, a fresh RPMI 1640 medium with 10\% FCS was added, and incubation continued for $42 \mathrm{~h}$. Sixteen hours prior to TNF treatment, cells were serum starved with an RPMI 1640 medium supplemented with $0.2 \%$ FCS; $10 \mathrm{ng} / \mathrm{mL}$ TNF (in PBS) (PeproTech, Hamburg, Germany) was used, as described previously [17]. Camptothecin or etoposide (all Sigma-Aldrich, St. Louis, MO, USA) were used at concentrations of $1 \mu \mathrm{M}$ (in DMSO) or $10 \mu \mathrm{M}$ (in DMSO), respectively.

\subsection{Subcellular Fractionation}

Cells were washed twice with PBS and scraped into chilled $1 \mathrm{~mL}$ PBS. After removing the PBS by centrifugation $(2 \mathrm{~min}, 1000 \times g)$, the cell pellet was suspended in $400 \mu \mathrm{L}$ chilled buffer A $(20 \mathrm{mM}$ 
Tris pH 7.9, $10 \mathrm{mM} \mathrm{NaCl}, 1.5 \mathrm{mM} \mathrm{MgCl} 2,10 \%$ glycerol, $1 \mathrm{mM}$ DTT, $0.5 \mathrm{mM} \mathrm{AEBSF}, 1 \mathrm{mM} \mathrm{Na}_{3} \mathrm{VO}_{4}$, $1 \mathrm{mM} \mathrm{Na}_{2} \mathrm{MO}_{4}, 10 \mathrm{mM} \mathrm{NaF}, 10 \mathrm{mM} \mathrm{K}_{2} \mathrm{HPO}_{4}, 20 \mathrm{mM}$ 2-Phosphoglycerate, $7.5 \mathrm{mM}$ N-Ethylmaleimid (NEM), $5 \mathrm{mM}$ ortho-phenanthroline (OPT), $1 \times$ cOmplete EDTA-free protease inhibitor cocktail (Roche Diagnostics, Mannheim, Germany)), and incubated for $10 \mathrm{~min}$ on ice. Subsequently, $4 \mu \mathrm{L}$ NP40 was added to lyse the cells. After $5 \mathrm{~min}$ incubation on ice, nuclei were separated from cytosolic supernatants by centrifugation $(10 \mathrm{~min}, 2000 \times \mathrm{g})$. Cytosolic supernatants were clarified by centrifugation ( $10 \mathrm{~min}, 13,000 \times g)$, and nuclear pellets washed with $100 \mu \mathrm{L}$ buffer A. Nuclear pellets were suspended in $50 \mu \mathrm{L}$ buffer C $(20 \mathrm{mM}$ Tris pH 7.9, $420 \mathrm{mM} \mathrm{NaCl}, 1.5 \mathrm{mM}$ $\mathrm{MgCl}_{2}, 10 \%$ glycerol, $0.2 \mathrm{mM}$ EDTA, $0.5 \mathrm{mM}$ DTT, $0.5 \mathrm{mM}$ AEBSF, $1 \mathrm{mM} \mathrm{Na} \mathrm{VO}_{4}, 1 \mathrm{mM} \mathrm{Na} \mathrm{MO}_{4}$, $10 \mathrm{mM} \mathrm{NaF}, 10 \mathrm{mM} \mathrm{K} \mathrm{HPO}_{4}, 20 \mathrm{mM}$ 2-Phosphoglycerate, $7.5 \mathrm{mM}$ NEM, $5 \mathrm{mM}$ OPT, $1 \times$ cOmplete EDTA-free protease inhibitor cocktail), and incubated for $30 \mathrm{~min}$ on ice, with occasional vortexing. Soluble nuclear proteins (N1) were obtained after centrifugation $(10 \mathrm{~min}, 13,000 \times g)$. The BCA assay (Thermo Fisher Scientific) was used to determine protein concentration.

\subsection{SDS-PAGE and Immunoblotting}

Proteins were separated by SDS-PAGE in Tris-Glycine buffer gels and transferred onto PVDF membranes (Merck, Darmstadt, Germany), followed by $1 \mathrm{~h}$ blocking at room temperature using 5\% skim milk in TBS containing 0.1\% Tween (TBS-T). The PVDF membranes were incubated overnight at $4{ }^{\circ} \mathrm{C}$, with the primary antibodies in either $5 \%$ BSA or $5 \%$ skim milk/TBS-T. The membranes were washed thrice with TBS-T, and incubated with the appropriate HRP-conjugated secondary antibody diluted 1:5000 in 5\% skim milk/TBS-T for $1 \mathrm{~h}$ at room temperature. All antibodies used in this study are listed in the Supplementary Materials Table S1. After washing the membranes thrice with TBS-T, the blots were developed using a chemiluminescent substrate (Merck), and protein bands were visualized using the ChemoCam Imager (Intas, Göttingen, Germany).

\subsection{Apoptosis Detection}

Forty-eight hours after transfection, cells were treated for $24 \mathrm{~h}$ with either camptothecin or etoposide. Control cells were treated with equal volumes of DMSO. Externalization of phosphatidylserine was determined $24 \mathrm{~h}$ after treatment using the Annexin V-FITC kit (Biotool, Houston, TX, USA). Cells were labeled with Annexin V-FITC according to instructions, and, apoptotic cells (Annexin V-FITC positive) were counted by flow cytometry (CyFlow space, Partec, Görlitz, Germany). Whole cell extracts for immunoblotting were prepared by suspending the cells in $100 \mu \mathrm{L}$ RIPA buffer (50 mM Tris, $\mathrm{pH} 7.5,150 \mathrm{mM} \mathrm{NaCl}, 10 \mathrm{mM} \mathrm{K}_{2} \mathrm{HPO}_{4}, 5 \mathrm{mM}$ EDTA, 10\% glycerol, $1 \%$ Triton X100, 0.05\% SDS, $1 \mathrm{mM}$ AEBSF, $20 \mathrm{mM}$ 2-phosphoglycerate, $20 \mathrm{mM} \mathrm{NaF}, 1 \mathrm{mM}{ }_{3} \mathrm{VO}_{4}$, $1 \mathrm{mM} \mathrm{Na} 2 \mathrm{MoO}_{4}, 1 \times$ cOmplete EDTA-free protease inhibitor cocktail), followed by 10 min incubation on ice, and subsequent clarification of the extract $(10 \mathrm{~min}, 13,000 \times \mathrm{g})$.

\subsection{Cell Viability Assay}

Cells were seeded in 96-well plates with 50,000 cells per well, and transfected as described above. Twenty-four hours after camptothecin or etoposide, treatment viability was assessed using the MTT Cell Viability Assay Kit (Abnova, Taipei, Taiwan). Assays were performed according to instructions, and absorption was measured at $570 \mathrm{~nm}$ on a Spectramax M5 plate reader (Molecular Devices $\mathrm{GmbH}$, Biberach an der Riss, Germany). The average absorption value for the control cells was set to $100 \%$ viability.

\subsection{Statistics}

All quantitative data were presented as mean \pm S.D (standard deviation). Statistical analysis was performed using Student's $t$-test (Excel, Microsoft Office Plus 2010). $p<0.05$ was regarded as significant. 


\section{Results}

\subsection{Depletion of USP47 Decreased Phospho-RelA and BTrCP Protein Levels}

Based on the observation that USP47 promotes the proliferation of gastric carcinomas [19], we performed a USP47 knockdown in AGS gastric carcinoma cells. Stimulation with tumor necrosis factor (TNF) for up to $20 \mathrm{~min}$ in USP47 knockdown cells resulted in decreased Ser536-phosphorylated RelA protein levels in the cytosol, and to a minor extent, also in the nucleus (Figure 1A). In contrast, $\mathrm{I} \kappa \mathrm{B} \alpha$ degradation appeared unaffected, even though a minor decrease in I $\mathrm{B} \alpha$ phosphorylation was noticed after USP47 knockdown (Figure 1A). Analysis of regulatory NF- $\kappa$ B pathway components revealed that USP47 depletion constitutively decreased $\beta$ TrCP levels (Figure $1 \mathrm{~A}$ ). $\beta \operatorname{TrCP}$ is the substrate adaptor of the E3 ligase complex that facilitates I $\mathrm{K} \mathrm{B} \alpha$ ubiquitinylation after phosphorylation. Inhibition of protein translation through cycloheximide (CHX) treatment showed that USP47 depletion decreased the basal expression levels of $\beta$ TrCP (Figure 2). Similar to AGS cells, knockdown of USP47 in gastric cancer cell line (NCI-N87) constitutively decreased $\beta$ TrCP levels, and reduced nuclear translocation of RelA (Figure 1B).

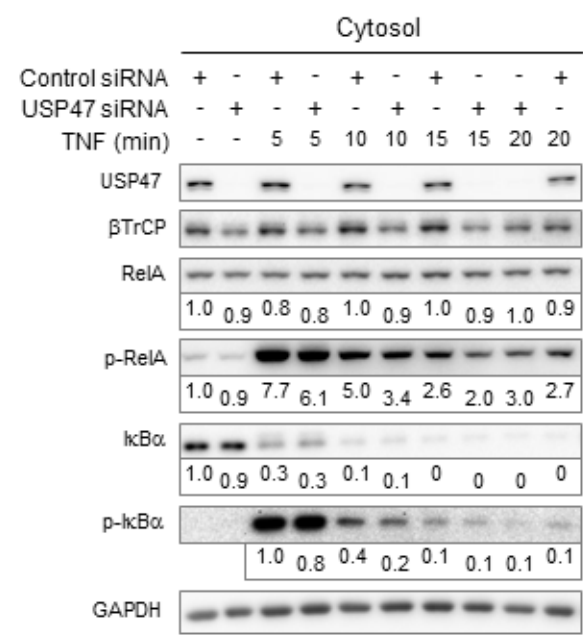

B

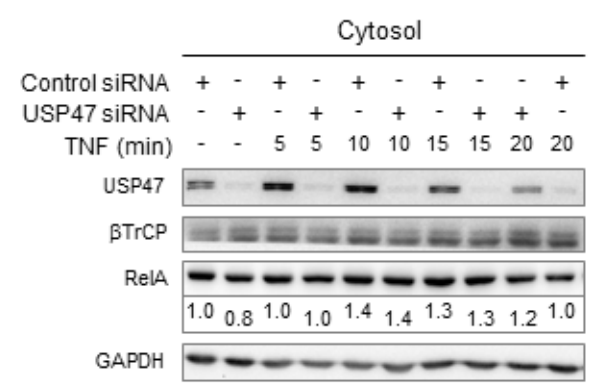

AGS

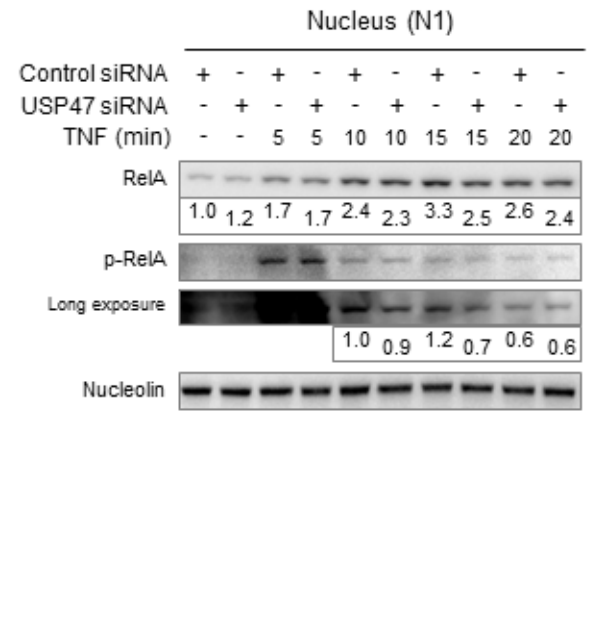

NCI-N87

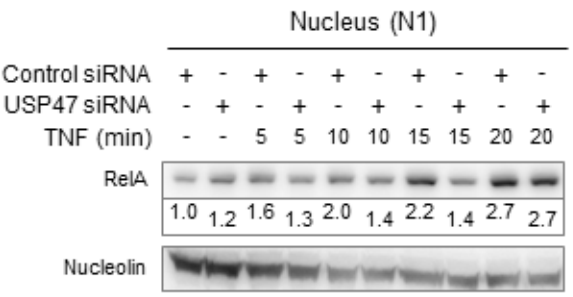

Figure 1. USP47 depletion downregulates protein levels of $\beta \operatorname{TrCP}$ and Ser536-phosphorylated RelA. (A) AGS or (B) NCI-N87 cells transfected with USP47 or a negative control siRNA were stimulated with TNF for up to $20 \mathrm{~min}$. Subcellular fractions were prepared at the indicated time points and NF- $\kappa B$ pathway components analyzed in cytosolic and soluble nuclear fractions (N1). An additional immunoblot with increased signal acquisition time is shown for p-RelA in (A). Detection of GAPDH and nucleolin served as control for equal protein load. For densitometric analysis, band intensities of key proteins were normalized to the band intensities of the respective cytosolic or nuclear loading control. The normalized band intensities are shown below the corresponding blots. 


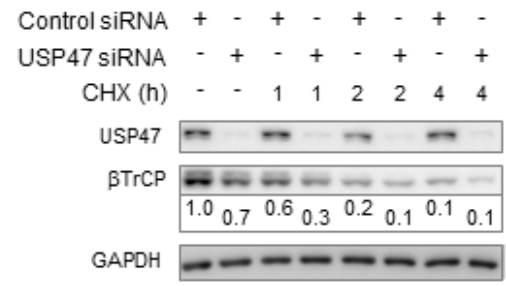

Figure 2. USP47 depletion downregulates basal $\beta$ TrCP protein levels. AGS cells transfected with USP47 or a negative control siRNA were treated with CHX for up to $4 \mathrm{~h}$. Subcellular fractions were prepared at the indicated time points and $\beta \operatorname{TrCP}$ stability was analyzed in the cytosolic fractions.

\subsection{USP47 Promotes Chemoresistance and Cell Viability in NCI-N87 Gastric Carcinoma Cells}

TNF can induce diverse cellular responses, including cell survival and apoptosis [21]. Gastric cancer patients have low cure rates after chemotherapy; we therefore asked whether USP47 knockdown could enhance apoptosis in gastric cancer cells when treated with chemotherapeutic drugs. We selected the topoisomerase I and II inhibitors CPT and Eto to treat different gastric carcinoma cell lines, because their mode of action is similar to drugs used in current chemotherapy regimens [3], and because they are known to also promote NF-KB-dependent apoptosis resistance [22,23]. Eto or CPT treatment of AGS cells increased apoptotic cell death by ca. $18 \%$ or $38 \%$ in a concentration dependent-manner, respectively, (Figure 3A-C), promoted caspase 8, caspase 3, and poly(ADP-Ribose) polymerase (PARP)-1 cleavage (Figure 3D), and decreased cell viability by ca. 20\% (Figure 4). Combining USP47 knockdown with Eto or CPT treatment did not further enhance apoptotic cell death, and resulted in comparable levels of apoptotic cells and cell viability (Figure 3C,D and Figure 4).

A

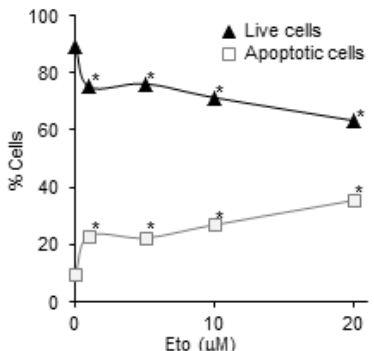

C

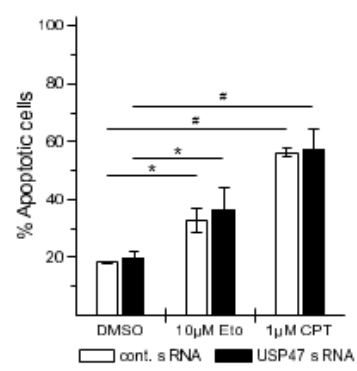

B

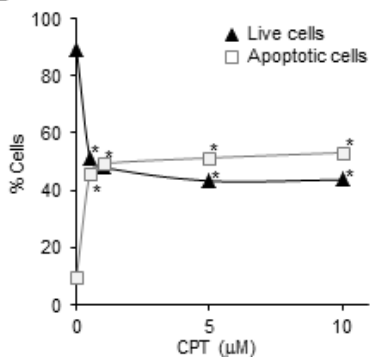

D

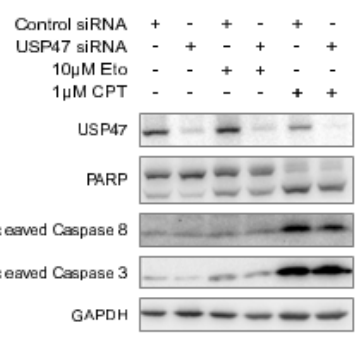

Figure 3. Etoposide (Eto) or camptothecin (CPT) induce apoptosis in AGS cells. $24 \mathrm{~h}$ after incubation of AGS cells with increasing amounts of (A) Eto $(1-20 \mu \mathrm{M})$ or $(\mathbf{B})$ CPT $(0.5-10 \mu \mathrm{M})$ live (black triangles) and apoptotic cells (open squares) were counted by flow cytometry using Annexin V staining. Standard deviations are in the range of the marker size. ${ }^{*} p<0.05$. USP47 depletion does not enhance Eto or CPT-induced apoptosis in AGS cells. AGS cells were incubated with $10 \mu \mathrm{M}$ Eto or $1 \mu \mathrm{M} \mathrm{CPT}$ for $24 \mathrm{~h}$ alone or in combination with USP47 knockdown; (C) Apoptotic cells were counted by flow cytometry using Annexin V staining. ${ }^{*} p<0.05, \# p<0.001$; (D) Whole cell extracts were subjected to immunoblotting and analyzed for apoptotic markers. Detection of GAPDH served as control for equal protein load. 
Analysis of additional gastric carcinoma cell lines showed that the NCI-N87 cell line was resistant to Eto and CPT treatment, independent of the concentration (Figure 5A,B). Interestingly, after USP47 knockdown, the NCI-N87 cell line displayed increased apoptotic cell death (Figure 5C), increased cleavage of PARP, caspase 3, and caspase 8 (Figure 5D), and reduced cell viability (Figure 6).

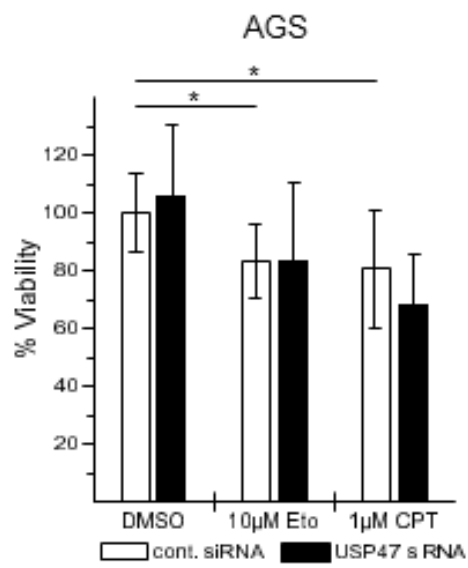

Figure 4. USP47 promotes cell viability in AGS cells. AGS cells were seeded in 96 well plates, transfected with control or USP47 siRNA and incubated for $24 \mathrm{~h}$ with either with $10 \mu \mathrm{M}$ Eto or $1 \mu \mathrm{MCPT}$. Cell viability was measured using the 3-(4,5-Dimethylthiazol-2-yl)-2,5-diphenyltetrazoliumbromid (MTT) assay. ${ }^{*} p<0.05$.

A

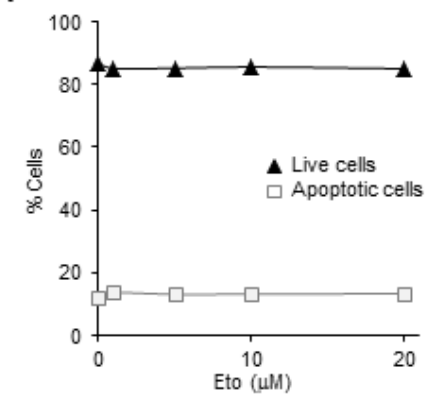

C

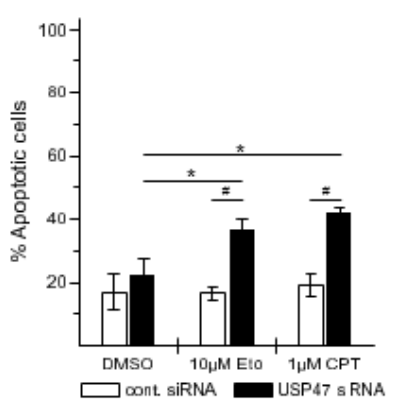

B

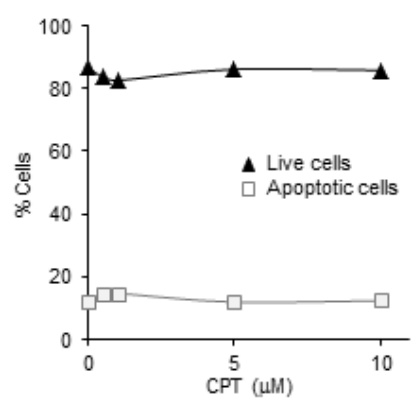

D

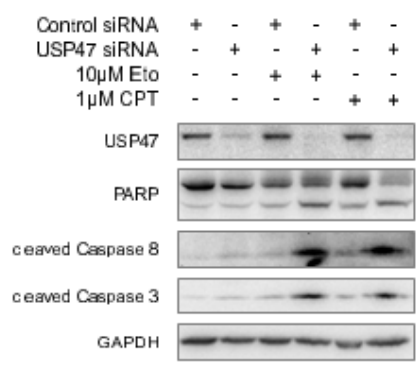

Figure 5. USP47 attenuates etoposide (Eto) or camptothecin (CPT)-induced apoptotic cell death in NCI-N87 cells. NCI-N87 cells were incubated with increasing concentrations of (A) Eto $(1-20 \mu \mathrm{M})$ or (B) CPT $(0.5-10 \mu \mathrm{M})$ for $24 \mathrm{~h}$. Live (black triangles) and apoptotic cells (open squares) were counted by flow cytometry using Annexin V staining. Standard deviations are in the range of the marker size; (C) To analyze the effect of USP47 on cell survival, NCI-N87 cells were transfected with USP47 or control siRNA, treated for $24 \mathrm{~h}$ with $10 \mu \mathrm{M}$ etoposide or $1 \mu \mathrm{M}$ CPT and apoptotic cells were counted by flow cytometry using Annexin V staining. ${ }^{*} p<0.05, \# p<0.001$; (D) Whole cell extracts of NCI-N87 cells treated as in (C) were subjected to immunoblotting and analyzed for apoptotic markers. Detection of GAPDH served as control for equal protein load. 


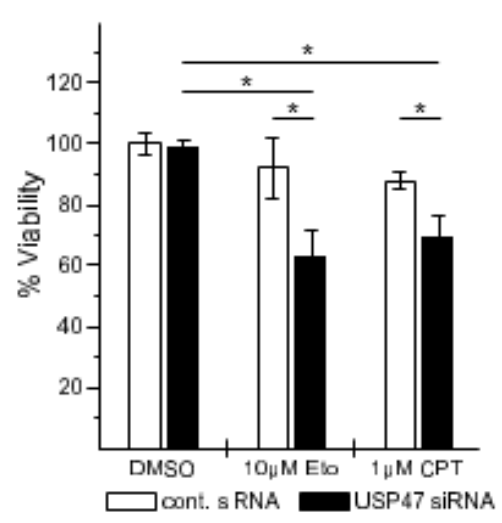

Figure 6. USP47 promotes cell viability in NCI-N87 cells. NCI-N87 cells were seeded in 96 well plates, transfected with control or USP47 siRNA and incubated for $24 \mathrm{~h}$ with either with $10 \mu \mathrm{M}$ Eto or $1 \mu \mathrm{MCPT}$. Cell viability was measured using the 3-(4,5-Dimethylthiazol-2-yl)-2,5-diphenyltetrazoliumbromid (MTT) assay. ${ }^{*} p<0.05$.

\section{Discussion}

After cardiovascular diseases, cancer is the second leading cause of death worldwide, and with an increasing and ageing population, it is expected that patient numbers will rise [1]. Chemoresistance constitutes a major problem of chemotherapy, because it promotes relapse and thus increases morbidity [4]. Therefore, it is necessary to improve current chemotherapy regimens and identify new drug targets, especially for malignancies like gastric carcinomas with low cure rates [3]. Deubiquitinylases represent promising novel targets for drug discovery in cancer therapy, due to their involvement in metastasis and their regulatory role in apoptosis pathways [24]. In this study we could identify USP47 as a regulator of the NF- $\mathrm{KB}$ pathway. Therapeutic intervention of NF- $\mathrm{KB}$ signaling is an intensively studied research field $[18,25]$, because aberrant NF- $\mathrm{KB}$ activation in the context of cancer promotes carcinogenesis, tumor progression, metastasis, or chemoresistance [5].

Our results demonstrate that USP47 stabilizes the E3 ligase complex substrate adaptor protein $\beta \operatorname{TrCP}$, and promotes phosphorylation of RelA at Ser536 (Figure 1). The residual $\beta \operatorname{TrCP}$ levels after USP47 depletion suffice to allow for I $\mathrm{\kappa} B \alpha$ degradation. Within the chosen time points, differences between USP47 and control cells did not become apparent, probably due to the rapidness of the process. Nonetheless, nuclear translocation of RelA is diminished after USP47 knockdown (Figure 1), which is consistent with a delayed release from I $\mathrm{K} B \alpha$.

Apart from its regulatory role in the NF- $\mathrm{kB}$ pathway, USP47 constitutes an interesting target for gastric cancer chemotherapy, because it promotes gastric carcinoma cell proliferation [19], and its depletion sensitize cancer cells to chemotherapy, probably due to the upregulation of Cdc25a [20]. We therefore addressed the question of whether USP47 inhibition could affect cell survival/proliferation of gastric cancer cells. For instance, USP47 inhibition could be beneficial in attenuating NF- $\mathrm{kB}$-dependent chemoresistance in response to DNA double strand break inducing agents [22]. AGS cells displayed pronounced apoptotic cell death when treated with CPT or Eto (Figure 3A-D), but no further enhancement was observed after USP47 depletion. It is likely that the already strong response masks additional contributions to the apoptosis caused by the USP47 knockdown. Interestingly, in the CPT- and Eto-resistant gastric carcinoma cell line NCI-N87 (Figure 5A,B) USP47 depletion resulted in pronounced apoptosis induction after CPT and Eto treatment (Figure 5C,D and Figure 6). The molecular mechanisms responsible for the drug-resistance are currently unknown. However, it is likely that in addition to the attenuation of NF-KB activity, other factors involved in DNA double strand break repair might play a role. For instance, USP47 stabilizes DNA polymerase $\beta$, and hence regulates base excision repair after DNA damage [26]. Similarly, USP47 might 
stabilize protein factors involved in DNA double strand break repair, and hence, depletion of USP47 could sensitize cancer cells to the action of DNA damaging agents.

USP47 depletion on its own caused no increase in apoptotic cell death (Figures 3-6), suggesting that loss of USP47 activity is not cytotoxic. This together with its potential to overcome chemoresistance in gastric carcinoma cells suggests that USP47 could represent a promising therapeutic target structure. Furthermore, a combination of current chemotherapy regimens together with USP47 inhibition might allow the reduction of the concentration of chemotherapeutic agents without impairing the cytotoxic effect on cancer cells, while reducing side effects. We propose that the development of USP47 inhibitors and their combination with current chemotherapy regimens might reduce relapse after gastrectomy, and extend overall patient survival times.

\section{Conclusions}

Here, we could show that USP47 regulates NF- $\mathrm{B}$ activity by promoting the phosphorylation of RelA through the stabilization of $\beta \operatorname{TrCP}$ and subsequent degradation of IKB $\alpha$. In addition, USP47 contributes to chemoresistance and viability in NCI-N87 gastric carcinoma cells. Inhibition of USP47 activity could represent a viable strategy for gastric cancer chemotherapy by downregulating transcription of NF-kB-regulated pro-survival genes, and overcoming NF-kB-dependent chemoresistance.

Supplementary Materials: The following are available online at http://www.mdpi.com/2227-9059/6/2/62/s1, Table S1: List of primary and secondary antibodies: Uncropped immunoblots corresponding to data shown in this study.

Author Contributions: M.N. conceived the study; M.N., L.N. and M.S. designed the experiments; L.N. performed the flow cytometry and cell viability assays of AGS and NCI-N87 cells; M.S. performed subcellular fractionations and subsequent immunoblot analysis of NF- $\mathrm{kB}$ components; A.G. contributed to RNAi optimization and immunoblotting; M.N., M.S. and L.N. wrote the paper.

Acknowledgments: The work was supported by the Ministery of Economy, Science and Digitalisation (Förderung von Wissenschaft und Forschung in Sachsen-Anhalt aus Mitteln der Europäischen Struktur- und Investitionsfonds in der Förderperiode 2014-2020, ZS/2016/04/78155) and a stipend from the Medical Faculty of the Otto von Guericke University to L.N.

Conflicts of Interest: The authors declare no conflict of interest.

\section{References}

1. Global Burden of Disease Cancer Collaboration. Global, regional, and national cancer incidence, mortality, years of life lost, years lived with disability, and disability-adjusted life-years for 32 cancer groups, 1990 to 2015: A systematic analysis for the global burden of disease study. JAMA Oncol. 2017, 3, 524-548. [CrossRef]

2. Orditura, M.; Galizia, G.; Sforza, V.; Gambardella, V.; Fabozzi, A.; Laterza, M.M.; Andreozzi, F.; Ventriglia, J.; Savastano, B.; Mabilia, A.; et al. Treatment of gastric cancer. World J. Gastroenterol. 2014, 20, 1635-1649. [CrossRef] [PubMed]

3. Wagner, A.D.; Syn, N.L.; Moehler, M.; Grothe, W.; Yong, W.P.; Tai, B.-C.; Ho, J.; Unverzagt, S. Chemotherapy for advanced gastric cancer. Cochrane Database Syst. Rev. 2017. [CrossRef] [PubMed]

4. Zheng, H.-C. The molecular mechanisms of chemoresistance in cancers. Oncotarget 2017, 8, 59950-59964. [CrossRef] [PubMed]

5. Sokolova, O.; Naumann, M. NF-кB Signaling in Gastric Cancer. Toxins 2017, 9, 119. [CrossRef] [PubMed]

6. Neumann, M.; Naumann, M. Beyond IkBs: Alternative regulation of NF-kB activity. FASEB J. 2007, 21, $2642-2654$. [CrossRef] [PubMed]

7. Maeda, S.; Omata, M. Inflammation and cancer: Role of nuclear factor-kappaB activation. Cancer Sci. 2008, 99, 836-842. [CrossRef] [PubMed]

8. Kwon, H.-C.; Kim, S.-H.; Oh, S.Y.; Lee, S.; Lee, J.H.; Jang, J.S.; Kim, M.C.; Kim, K.H.; Kim, S.-J.; Kim, S.-G.; et al. Clinicopathologic significance of expression of nuclear factor- $\mathrm{B}$ RelA and its target gene products in gastric cancer patients. World J. Gastroenterol. 2012, 18, 4744-4750. [CrossRef] [PubMed] 
9. Manu, K.A.; Shanmugam, M.K.; Li, F.; Chen, L.; Siveen, K.S.; Ahn, K.S.; Kumar, A.P.; Sethi, G. Simvastatin sensitizes human gastric cancer xenograft in nude mice to capecitabine by suppressing nuclear factor-kappa B-regulated gene products. J. Mol. Med. 2014, 92, 267-276. [CrossRef] [PubMed]

10. Zhou, W.; Fu, X.-Q.; Zhang, L.-L.; Zhang, J.; Huang, X.; Lu, X.-H.; Shen, L.; Liu, B.-N.; Liu, J.; Luo, H.-S.; et al. The AKT1/NF-kappaB/Notch1/PTEN axis has an important role in chemoresistance of gastric cancer cells. Cell Death Dis. 2013, 4, e847. [CrossRef] [PubMed]

11. Kinoshita, J.; Fushida, S.; Harada, S.; Makino, I.; Nakamura, K.; Oyama, K.; Fujita, H.; Ninomiya, I.; Fujimura, T.; Kayahara, M.; et al. PSK enhances the efficacy of docetaxel in human gastric cancer cells through inhibition of nuclear factor-kB activation and survivin expression. Int. J. Oncol. 2010, 36, 593-600. [CrossRef] [PubMed]

12. Clague, M.J.; Barsukov, I.; Coulson, J.M.; Liu, H.; Rigden, D.J.; Urbé, S. Deubiquitylases from Genes to Organism. Physiol. Rev. 2013, 93, 1289-1315. [CrossRef] [PubMed]

13. Harrigan, J.A.; Jacq, X.; Martin, N.M.; Jackson, S.P. Deubiquitylating enzymes and drug discovery: Emerging opportunities. Nat. Rev. Drug Discov. 2017, 17, 57. [CrossRef] [PubMed]

14. Li, W.; Bengtson, M.H.; Ulbrich, A.; Matsuda, A.; Reddy, V.A.; Orth, A.; Chanda, S.K.; Batalov, S.; Joazeiro, C.A.P. Genome-Wide and Functional Annotation of Human E3 Ubiquitin Ligases Identifies MULAN, a Mitochondrial E3 that Regulates the Organelle's Dynamics and Signaling. PLoS ONE 2008, 3, e1487. [CrossRef] [PubMed]

15. Wertz, I.E.; Dixit, V.M. Signaling to NF-кB: Regulation by Ubiquitination. Cold Spring Harb. Perspect. Biol. 2010, 2, a003350. [CrossRef] [PubMed]

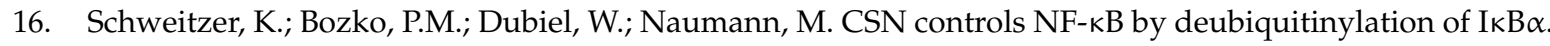
EMBO J. 2007, 26, 1532-1541. [CrossRef] [PubMed]

17. Schweitzer, K.; Naumann, M. CSN-associated USP48 confers stability to nuclear NF- $\mathrm{B} /$ RelA by trimming K48-linked Ub-chains. Biochim. Biophys. Acta 2015, 1853, 453-469. [CrossRef] [PubMed]

18. Erstad, D.J.; Cusack, J.C. Targeting the NF-kB Pathway in Cancer Therapy. Transl. Cancer Res. Surg. 2013, 22, 705-746. [CrossRef] [PubMed]

19. Zhang, B.; Yin, Y.; Hu, Y.; Zhang, J.; Bian, Z.; Song, M.; Hua, D.; Huang, Z. MicroRNA-204-5p inhibits gastric cancer cell proliferation by downregulating USP47 and RAB22A. Med. Oncol. 2014, 32, 331. [CrossRef] [PubMed]

20. Peschiaroli, A.; Skaar, J.; Pagano, M.; Melino, G. The ubiquitin-specific protease USP47 is a novel $\beta$-TRCP interactor regulating cell survival. Oncogene 2010, 29. [CrossRef] [PubMed]

21. Varfolomeev, E.E.; Ashkenazi, A. Tumor Necrosis Factor: An Apoptosis JuNKie? Cell 2004, 116, $491-497$. [CrossRef]

22. Habraken, Y.; Piette, J. NF-kB activation by double-strand breaks. Biochem. Pharmacol. 2006, 72, $1132-1141$. [CrossRef] [PubMed]

23. Choi, Y.S.; Jeong, S. PI3-Kinase and PDK-1 Regulate HDAC1-mediated Transcriptional Repression of Transcription Factor NF-kB. Mol. Cells 2005, 20, 241-246. [PubMed]

24. He, M.; Zhou, Z.; Wu, G.; Chen, Q.; Wan, Y. Emerging role of DUBs in tumor metastasis and apoptosis: Therapeutic implication. Pharmacol. Ther. 2017, 177, 96-107. [CrossRef] [PubMed]

25. Hoesel, B.; Schmid, J.A. The complexity of NF-kB signaling in inflammation and cancer. Mol. Cancer 2013, $12,86$. [CrossRef] [PubMed]

26. Parsons, J.L.; Dianova, I.I.; Khoronenkova, S.V.; Edelmann, M.J.; Kessler, B.M.; Dianov, G.L. USP47 Is a Deubiquitylating Enzyme that Regulates Base Excision Repair by Controlling Steady-State Levels of DNA Polymerase $\beta$. Mol. Cell 2011, 41, 609-615. [CrossRef] [PubMed]

(C) 2018 by the authors. Licensee MDPI, Basel, Switzerland. This article is an open access article distributed under the terms and conditions of the Creative Commons Attribution (CC BY) license (http:/ / creativecommons.org/licenses/by/4.0/). 